\title{
ע Muistisairauteen sopeutumisen tarinatyypit työikäisenä sairastuneilla ja heidän läheisillään
}

\author{
Katja Hautsalo ${ }^{1,2}$, Jari Pirhonen $^{1}$, Ilkka Pietilä $^{1}$ \\ ${ }^{1}$ Valtiotieteellinen tiedekunta (sosiaaligerontologia), Helsingin yliopisto \\ ${ }^{2}$ Tampereen ammattikorkeakoulu
}

\begin{abstract}
Työikäisenä muistisairauteen sairastuminen rikkoo oletetun elämänkulun, vaatien sopeutumista ja elämäntarinan uudelleenrakentamista. Tutkimuksessa selvitettiin työikäisenä sairastuneiden ja heidän läheistensä haastatteluiden $(n=26)$ perusteella, kuinka sairastuneet jäsentävät muistisairauden aiheuttamia elämänmuutoksia sairauden alkuvaiheessa ja miten läheisen tarina resonoi sairastuneen tarinan kanssa. Analyysissä havaittiin kolme erilaista tarinatyyppiä. Kaaoksen tarinaa leimasi sairastumisen aiheuttama elämän epävarmuus ja organisoimattomuus. Irtautumisen tarinassa päästettiin irti turhiksi koetuista asioista, kavennettiin elämänpiiriä ja keskityttiin hetkessä elämiseen. Aktiivisuuden tarinassa suunniteltiin tulevaisuutta, toimittiin aktiivisesti ja vahvistettiin omaa hyvinvointia sairautta vastustamalla. Läheisten ja sairastuneiden tarinoiden yhtäläisyys vaihteli tarinatyypeittäin. Sairastamisen alkuvaiheen kokemuksia ja tilanteeseen sopeutumista peilataan tutkimuksessa kulttuurisiin sairastamisen mallitarinoihin. Tällöin tarkastellaan, kuinka tarinallisuus on osa sairastumisen käynnistämää elämäntarinan uudelleenrakentamisen prosessia. Lisäksi pohditaan, miten työikäisenä sairastuneen henkilön hyvinvointia voidaan tukea huomioiden ihmisten erilainen suhtautuminen sairauteen. Tarvitaan ymmärrystä kulttuurisista sairastamisen mallitarinoista ja muistisairauden vaikutuksista yksilön sekä perheen tilanteeseen, jotta sairastuneita ja heidän läheisiään voidaan nykyistä tehokkaammin tukea sairauteen sopeutumisessa ja sopivan arjen aktiivisuuden ylläpitämisessä.
\end{abstract}

\section{Johdanto}

Suomessa sairastuu vuosittain noin 14500 ihmistä muistisairauteen, ja maassamme on tällä hetkellä arviolta noin 193000 muistisairasta henkilöä. Heistä yli 7000:1la on diagnosoitu muistisairaus työikäisenä. (Muistisairaudet. Käypä hoito -suositus, 2017). Työikäisenä eli alle 65-vuotiaana (YOD, young-onset dementia) muistisairauteen sairastuneet ovat erityinen ryhmä muistisairaiden joukossa, sillä heidän sairautensa eroaa vanhuusiän (LOD, late-onset dementia) muistisairaudesta. Sairauden alkuvaiheen oireet vaihtelevat ja sisältävät usein neurologisia oireita enemmän kuin iäkkäänä sairastuneella (Millenaar ym. 2016). Muistisairautta 
ei työikäisillä myöskään usein osata epäillä oireiden aiheuttajaksi. Fysiologisten sairauteen liittyvien oireiden erojen lisäksi eri ikäryhmien muistisairauksien sairastaminen eroaa toisistaan monin tavoin myös psyykkisestä ja sosiaalisesta näkökulmasta tarkasteltuna. Runsaasta tutkimustyöstä huolimatta muistisairauksiin ei ole kyetty kehittämään hoitoa tai lääkettä, mikä lisää sairauden tuottamaa uhan ja epävarmuuden tunnetta. (Birt ym. 2017; Higgs \& Gilleard 2017).

Työikäisenä muistisairauteen sairastuminen rikkoo radikaalilla tavalla odotetun elämänkulun (Johannessen ym. 2018), sillä sairaus ilmaantuu "väärään" aikaan, ja siihen on siksi vaikeaa valmistautua (Lockeridge \& Simpson 2013; Greenwood \& Smith 2016). Muistisairauden takia työelämästä poisjääminen voi aikaistua ja elämänvaiheeseen kuuluvat aktiiviset toimintamahdollisuudet heikentyä (Van Vilet ym. 2017). Sairastunut joutuu yleensä luopumaan itselleen merkityksellisestä toiminnasta, esimerkiksi autolla ajamisesta, ja vetäytymään monista vakiintuneista rooleistaan (Johannessen \& Möller 2013; Spreadbury \& Kipps 2019). Muistisairaus vaikuttaa monin tavoin myös sosiaalisiin suhteisiin ja tulevaisuuteen suhtautumiseen. Ihmissuhteissa esimerkiksi perheen sisäiset roolit ja työnjako muuttuvat sairauden edetessä (Van Vilet ym. 2017; Clemmensen ym. 2019). Myös läheisten tulee sopeutua tilanteeseen (Wawrziczny ym. 2017), ja sairastunut tulee yhä enemmän riippuvaiseksi muista ihmisistä. Sairastuminen käynnistää psyykkisen prosessin, joka sisältää erilaisia vaiheita, kuten sairauden hyväksymiseen liittyvää työstämistä, erilaisten sopeutumiskeinojen kehittelyä, suremista ja sairauteen liittyvän stigman läpikäyntiä (Spreadbury \& Kipps 2019).

Sairastuminen muuttaa ihmisen näkemystä omasta itsestään ja edellyttää siksi identiteetin työstämistä (Greenwood \& Smith 2016; Johannessen ym. 2018). Myös tulevaisuuteen täytyy orientoitua uudelleen (Spreadbury \& Kipps 2019), koska sairastuminen saattaa murentaa aikaisemmin tehtyjä tulevaisuuden suun- nitelmia (Johannessen ym. 2018). Kuten monet muutkin pitkäaikaissairaudet, myös muistisairaus edellyttää oman elämänkulun uudenlaista hahmottamista, kun sairaudelle on rakennettava elämäntarinaan oma osuus.

\section{Muistisairaus ja elämäntarinan uudelleen rakentaminen}

Suuret elämänmuutokset, kuten sairastuminen, edellyttävät sopeutumista uuteen tilanteeseen. Buryn (1982) mukaan sairastuminen pitkäaikaiseen ja etenevään sairauteen aiheuttaa "elämäkerrallisen häiriön" (biographical disruption) ja käynnistää prosessin, jossa arkielämän ja sitä tukevan tietämyksen rakenne muuttuu ja tietoisuus kärsimyksestä sekä elämän rajallisuudesta lisääntyy. Jotta sairauteen voi sopeutua, tulee huomioida käytettävissä olevat voimavarat ja tilanteeseen sopeutumista rajoittavat tekijät. Sopeutumisen prosessista on käytetty englanninkielisiä termejä reorientation (Hänninen 1996) ja narrative reconstruction (Williams 1984). Uudelleen orientoitumisella (reorientation) tarkoitetaan suuren elämänmuutoksen jälkeistä prosessia, jossa ihminen käy läpi arvojaan, tietoperustaansa sekä identiteettiään. Nämä osa-alueet luovat perustan ihmisen oman elämän kertomukselle, sisäiselle tarinalle, jonka avulla ihminen ymmärtää ja tulkitsee omaa elämänkulkuaan, tilannettaan sekä elämänsä merkityksellisiä asioita. Sisäisen tarinan ja todellisten elämän olosuhteiden tulee vastata toisiaan. (Hänninen 1996.) Elämäntarinan uudelleen rakentamisen (narrative reconstruction) teoria liittyy pitkäaikaissairauden aiheuttaman elämäkerrallisen katkoksen huomioimiseen ja häiriön korjaamiseen. Uudelleen rakentamisessa sairastunut muodostaa uudenlaista suhdetta kehon, minän ja ympäristön välillä. Hän hyödyttää aikaisempaa elämänkokemustaan sovittaessaan uudessa tilanteessa itseään yhteiskuntaan sekä muodostaa käsityksen sairastumisensa syistä ja merkityksestä. (Williams 1984.)

Pitkäaikaissairaus vaikuttaa monin tavoin sairastuneen elämään, kun erilaiset sairauden 
aiheuttamat muutokset muokkaavat jatkuvasti sairastamiseen liittyviä kokemuksia (Hydén 1997). Kielellä ja tarinallisuudella on tärkeä asema sosiaalisen todellisuuden sekä ihmisen itseymmärryksen muodostumisessa. Ihmisen käsitys itsestään ja elämästään kuvataan usein koherentin kertomuksen muotoisena (Saarenheimo 1997). Hännisen mukaan yksilön sisäistä tarinaa muokkaa jatkuvasti neljä ulottuvuutta: Situaatio tarkoittaa elämäntilanteen kokonaisuutta ja tilannetekijöitä, joita ihminen tulkitsee sisäisessä tarinassaan. Toinen ulottuvuus on ihmisen toiminta, jota sisäinen tarina ohjaa, ja kolmas sosiaalinen tietovaranto, joka sisältää ihmisen omaksumia, kulttuurissa jaettuja kertomuksia. Neljäs ulottuvuus on kertomus. Siinä ihminen kertoo tarinaa, tavallisimmin jo toteutuneista asioista, saaden muilta sosiaalista vahvistusta sekä mahdollisuuden reflektoida kokemustaan. Kertominen antaa kokemuksille ulkoisen muodon, ja sairauteen liittyvissä kertomuksissa sairastunut jäsentää ja muovaa kokemustaan niiden avulla. (Hänninen 1996; 1999.) Työikäisenä muistisairauteen sairastuneen kohdalla heikentyvä kognitio samoin kuin sairauden aiheuttamat suuret elämänmuutokset haastavat erityisen vahvasti tarinallisen jatkuvuuden ja mahdollisuuden kokea merkityksellisyyttä (Heimonen 2005).

Tarinan kertominen kuuluu osana sairastumisen käynnistämään uudelleenrakennusprojektiin, ja sitä kerrotaan itselle ja muille. Tarinan kertominen itselle auttaa sairastunutta näkemään tilanteensa ja rakentamaan käsitystä itsestään. Tarinan kertominen muille ihmisille, kuten läheisille, terveydenhuollon henkilöstölle, työnantajalle ja kollegoille, on usein välttämätöntä, halusipa sairastunut sitä tai ei. Esimerkiksi avunsaanti ja byrokratia voivat edellyttää tarinan kertomista. (Frank 2013.) Tutkimushaastattelut ovat yksi konteksti, jossa sairastunut kertoo sairauskokemuksistaan usein tarinan muodossa. Yksilöllisiä kokemuksiaan kuvaava ihminen kertoo samalla myös laajemmin oman kulttuurinsa yhteisestä kielestä, kokonaisuuksien jäsentämisen tavoista sekä merkityksien tulkinnasta. Kulttuuriset mallitarinat ovat osa sitä sosiaalista todellisuutta, jossa henkilö elää, ja ne vaikuttavat yksilön kokemukseen. Yksilöt eivät luo mallitarinoita itse vaan pyrkivät sopeutumaan (Saarenheimo 1997) vertaamalla, sovittamalla ja mukauttamalla niihin henkilökohtaisia kokemuksiaan (Pietilä ym. 2018).

\section{Muistisairauteen liittyvät kulttuuriset mallitarinat}

Sairauden luonne, sen aiheuttamat oireet ja muutokset sekä toipumisen mahdollisuudet vaikuttavat siihen, miten sairaus koetaan ja kuinka sairaus liitetään omaan elämään ja sitä kuvaavaan tarinaan (Pietilä ym. 2018). Frank (2013) on luokitellut kolme kulttuurista sairastamista kuvaavaa mallitarinaa: palauttamisen tarina (restitution narrative), kaaoksen tarina (chaos narrative) ja etsinnän tarina (quest narrative). Palauttamisen tarinassa sairaus nähdään häiriönä,joka tulee nujertaa. Sairastunut tavoittelee mahdollisimman nopeaa tervehtymistä ja ennalleen palautumista, orientoituen ajallisesti tulevaan ja toimien aktiivisesti. Kaaostarina on päinvastainen: sairastunut on passiivinen uhri, jolta on viety tulevaisuus, eikä sekavasta tilanteesta ole ulospääsyä. Kuormittavat asiat kasautuvat, eikä sairastunut pysty kontrolloimaan tilannetta. Kaaoksen keskellä oleva ei myöskään pysty itse tuottamaan johdonmukaista tarinaa, vaan vasta etäisyys sairastumiseen mahdollistaa aikaisemman tilanteen kuvaamisen. Tarina sairaudesta etsimisenä sisältää sairauden hyväksymisen, sen mukanaan tuomien uusien mahdollisuuksien näkemisen sekä elämän uudelleen suuntaamisen.

Frankin typologiaa on hyödynnetty pitkäaikaissairauksien tutkimuksissa laajasti. Erityisenä kiinnostuksen kohteena on ollut se, millaisia mahdollisuuksia erilaiset sairaudet (ks. esim. keuhkoahtaumatauti, Pinnock ym. 2011; rintasyöpä, Coll-Planas \& Visa 2016) antavat elämäntarinan uudelleen hahmottamiseen, sillä sairauksien etenemisen nopeus 
ja vaikutukset elämään eroavat merkittävästi. Työikäisenä muistisairauteen sairastuneiden kohdalla on myös syytä pohtia, kuinka sairaus asettuu osaksi elämänkulkua ja sitä koskevia kulttuurisia mallitarinoita. Kolmatta ikää on kuvattu työelämän jälkeisenä elämänvaiheena, johon liittyviä kulttuurisia oletuksia ovat esimerkiksi toimintakykyisyys, aktiivisuus, valinnan vapaus, kuluttaminen, mahdollisuus osallistua ja harrastaa eli omistaa aikaa omalle hyvinvoinnille. Kolmannen iän käsitteen on nähty luovan myönteisempää kuvaa vanhenemisesta. Kritiikkinä on kuitenkin todettu, ettei kaikilla ole mahdollisuutta tai halua elää näiden odotusten mukaisesti. Kolmannen iän vahvat myönteiset näkökulmat saattavat myös tehdä rajan neljänteen ikään hyvin jyrkäksi ja vahvistaa sen kielteisiä piirteitä. (Karisto 2004.) Neljäs ikä nähdään elämän päätevaiheena, kuin mustana aukkona, josta ei ole paluuta; ihmisen oma toimijuus ja valinnanvapaus heikkenevät, ja hän on yhä riippuvaisempi muista (Gilleard \& Higgs 2010; Williams ym. 2012).

Työikäisenä muistisairauteen sairastuminen rikkoo normaalin elämänkulun, ja kolmannen iän vaihe voi jäädä lyhyeksi, koska sairauden aiheuttamat muutokset jouduttavat siirtymistä neljänteen ikään. Neljänteen ikään liitetään Gulletten (2018) mukaan jatkuvan heikentymisen mallitarina (narrative of decline), johon kuuluu sairauksien kirjo, kehon heikkous ja hauraus sekä psyykkisen toimintakyvyn heikentyminen. Heikentymisen mallitarinaan kuuluvat myös autonomian menettäminen ja vanhenemiselle periksi antaminen (Pirhonen ym. 2015). Tällaisen mallitarinan vuoksi vanhat ihmiset voidaan nähdä itsestä erillisenä ja kaukaisena ihmisryhmänä, eli heidät toiseutetaan eikä heidän tilanteeseensa haluta samaistua. Samanlaisia yleistäviä ja stigmatisoivia heikentymisen tarinoita liitetään usein myös muistisairauksiin, riippumatta siitä minkä ikäinen sairastunut on. Muistin heikentyminen uhkaa vahvasti autonomiaa, rationaalisuutta, itsekontrollia sekä tunteiden hallintaa (Pirhonen ym. 2015) ja vie siksi ihmiseltä mahdollisuuksia elä̈, toimia ja vanheta kulttuurisesti hyväksytyllä tavalla (Williams ym. 2012).

Työikäisenä muistisairauteen sairastuneiden kokemuksia on tutkittu erilaisilla asetelmilla, ja useissa tutkimuksissa osallistujat ovat olleet hyvin eri vaiheissa sairautta $(\mathrm{mm}$. Johannessen \& Möller 2013; Clemerson ym. 2014; van Vilet ym. 2017; Rabanal ym. 2018). Tutkimuksilla on tuotettu monipuolista kuvaa työikäisten muistisairauden sairastamisesta. Sen sijaan on vähemmän sairauden alkuvaiheeseen liittyvää tutkimustietoa siitä, millaisia elämänmuutoksia nuorempana muistisairauteen sairastuminen aiheuttaa (ks. Heimonen 2005), kuinka sairauteen sopeudutaan muun muassa sen tarinallistamisen keinoin ja miten ympäristön suhtautuminen vaikuttaa sairastuneen kokemuksiin. Muistisairauden tarinallistamisesta haastavaa tekee sairauden moninaisuus. Muistisairaus on luonteeltaan etenevä, ja sen aiheuttamat oireet ovat yksilöllisiä ja monitahoisia ja vaikuttavat monin tavoin sairastuneen toimintaan (Birt ym. 2017). Sairauden moninaisuuden ymmärtämiseksi ja negatiivisten kulttuuristen olettamusten korjaamiseksi tarvitaan sairastuneiden kokemusten tutkimista ja heidän äänensä esille tuomista yhteiskunnassa (McParland ym. 2017). Siksi tässä artikkelissa tarkastellaan muistisairauteen työikäisenä sairastuneiden ja heidän läheistensä haastatteluiden pohjalta sitä, miten sairautta ja sen etenemistä kuvataan. Tarkennettuina tutkimuskysymyksinä ovat:

1. Kuinka sairastuneet jäsentävät sairauden aiheuttamia elämänmuutoksia sairauden alkuvaiheessa?

2. Miten läheisten tarinat sairaudesta resonoivat sairastuneiden tarinoihin?

\section{Aineisto}

Tutkimusaineisto koostuu 26 teemahaastattelusta, joista puolet on muistisairauteen sairastuneiden ja puolet heidän läheistensä haastatteluja. Osallistujat rekrytoitiin kahden eri sai- 
raanhoitopiirin neurologian poliklinikan kautta muistihoitajan ja/tai neurologin avulla sekä kaksi osallistujaparia muistiyhdistyksen kautta. Tutkimukseen osallistumisen kriteereiksi asetettiin se, että henkilölle oli tehty etenevän muistisairauden diagnoosi alle 65-vuotiaana ja että diagnoosin tekemisestä oli alle 6 kuukautta. Sairastunut nimesi itse läheisen henkilön, jonka pyysi osallistumaan tutkimukseen. Läheisen tuli osallistua säännöllisesti, vähintään viikoittain, sairastuneen arkeen. Molemmat, sairastunut ja läheinen, antoivat kirjallisen tietoisen suostumuksen tutkimukseen osallistumisesta. Sairastuneista 12 oli naisia ja yksi mies, ja he olivat iältään 51-65-vuotiaita. Diagnosoituja muistisairauksia olivat Alzheimerin tauti (11), Lewyn kappale -tauti (1) ja semanttinen dementia (1). Läheisistä yhdeksän oli puolisoita, kaksi äitiä ja kaksi lasta,ja heidän ikäjakaumansa oli 33-78 vuotta. Sairastuneista kaksi oli jatkanut työelämässä diagnoosin saamisen jälkeen ja loput yksitoista olivat jääneet pois työelämästä, mikä tarkoitti joko saatua eläkepäätöstä tai sen odottamista tai sairauslomalla olemista.

Muistisairautta sairastavilla henkilöillä on yhtäläinen oikeus osallistua tutkimuksiin kuin muillakin. Erityisen tärkeäksi osallistumisen tekee se, että tutkimus hyödyttää muita samassa tilanteessa olevia ihmisiä (Kuula 2011), ja monet tähän tutkimukseen osallistujat kertoivatkin lähteneensä mukaan juuri tämän vuoksi. Muistisairautta sairastavat pystyvät kuvaamaan sairauteensa liittyviä kokemuksia, vaikka sairaus vaikuttaakin tiedonkäsittelytoimintoihin (Johannessen ym. 2018). Muistisairauteen sairastuminen vaikuttaa myös läheisiin; he kohtaavat ja jakavat yhdessä sairastuneen kanssa haasteet, ovat osallisia uuteen tilanteeseen sopeutumisessa ja tukevat sairastunutta (Baptista ym. 2016). Läheisten tutkimukseen osallistumisen kautta on mahdollista saavuttaa laajempi ymmärrys sairauden aiheuttamista elämänmuutoksista.

Haastatteluiden toteutuksessa kiinnitettiin huomiota avoimeen ilmapiiriin, kiireettömyyteen ja vuorovaikutuksen selkeyteen. Jos sai- raus aiheutti haastattelutilanteessa havaittavia tiedonkäsittelytoimintojen haasteita, kuten kertomuksen katkeamista kesken tai sanojen muistamattomuutta, tuettiin sairastuneen itseilmaisua toistamalla avainsanoja, kertaamalla kysymyksiä sekä varmistamalla asioita lisäkysymyksin. Haastattelut kestivät (yhteiskesto sairastuneen ja läheisen haastatteluille) 70-165 minuuttia, ja litteroitujen haastatteluiden laajuus oli 15-28 sivua. Yhteensä litteroitua aineistoa oli 279 sivua.

Haastattelut toteutettiin sairastuneen kotona tai julkisen tilan neuvotteluhuoneessa silloin, kun kotona tapaaminen ei ollut mahdollista. Viisi haastattelua toteutettiin etänä, joko puhelinhaastatteluna tai videopuhelun avulla, kevään 2020 covid-19-pandemian poikkeusaikana. Haastattelut toteutti artikkelin ensimmäinen kirjoittaja. Haastattelun aluksi molemmille osallistujille kerrottiin suullisesti tutkimukseen osallistumiseen liittyviä tietoja ja annettiin mahdollisuus lisätietojen kysymiseen. Tämän jälkeen haastateltaville tehtiin vuorotellen yksilöhaastattelu, jossa käsiteltiin samat haastatteluteemat. Yhdessä haastattelussa molemmat haastateltavat halusivat olla koko ajan läsnä, ja tämä mahdollistettiin, kuitenkin niin, että heidänkin haastattelunsa tehtiin peräkkäin ja toinen vain kuunteli. Haastattelussa käsitellyt teemat olivat: sairauden ensimmäiset muutokset ja huolen herääminen, sairauden toteamisen prosessi, sairauden arjen elämään aiheuttamat muutokset, tuentarpeet ja sopeutumistavat, muiden ihmisten suhtautuminen sairastumiseen sekä tulevaisuuden suunnitelmat. Haastattelun jälkeen täytettiin CDRlomake (The Clinical Dementia Rating), jonka avulla kartoitettiin senhetkistä kognitiivista toimintakykyä eli sitä, miten sairaus vaikuttaa eri osa-alueisiin, esimerkiksi muistiin, orientaatioon tai yhteisöllisiin toimintoihin. Mittari täytettiin yhdessä sairastuneen ja hänen läheisensä kanssa, jotta molemmat saivat kertoa omat näkemyksensä ja perustelunsa luokituksen eri kohtiin, ja näiden pohjalta valittiin yhteisymmärryksessä sairauden tilannetta haas- 
tatteluhetkellä kuvaava luokka. CDR-asteikkoa on käytetty tässä tutkimuksessa sum of boxes -tyylisesti, mikä on yleinen tutkimuksissa käytetty tapa; siinä eri osioiden pistemäärät lasketaan yhteen ja tämä summa ilmoitetaan numerona (Rosenvall 2016). Tutkimukseen osallistujien CDR-asteikon yhteenlasketut sum of boxes -pisteet vaihtelivat $0-4,5: \mathrm{n}$ välillä, ollen neljällä sairastuneella 0 (normaali), kuudella 0,5-2,5 (epävarma heikentyminen), kahdella 3-4 (hyvin lievä dementia) ja yhdellä 4,5 (lievä dementia) (O’Bryant ym. 2008).

\section{Eettisyys ja luotettavuus}

Tutkimukselle on myönnetty puoltava lausunto Tampereen yliopistollisen sairaalan erityisvastuualueen eettiseltä toimikunnalta (R19023), ja tutkimuslupa osallistujien rekrytointia varten on saatu kahdesta sairaanhoitopiiristä. Tutkimuksen toteuttamisen kaikissa vaiheissa noudatettiin tutkimuseettisiä periaatteita eli tutkittavien itsemääräämisoikeutta, vahingoittumattomuutta ja yksityisyyden kunnioittamista (Kuula 2011). Tutkimukseen osallistujat saivat etukäteen kirjallista tutkimusinformaatiota, ja ennen haastattelua asiat käytiin myös suullisesti läpi. Yksityisyyden kunnioittamista varmisti se, että sairastuneen ja läheisen haastattelut tehtiin erikseen. Samanaikaisen haastattelun tekeminen voi estää kertomasta todellisista kokemuksista (Heimonen 2005; Clemerson ym. 2014).

Tutkimuksen luotettavuutta lisää se, että sairastuneet olivat melko samassa sairauden alkuvaiheessa sekä CDR-mittarin tulosten mukaan että sairauden diagnosoinnin ajankohtaa tarkasteltaessa. Kaikkien sairaus oli todettu aikaisintaan puoli vuotta ennen haastattelua. Tutkimuksen vahvuutena voidaan nähdä aineiston monipuolisuus. Niin sairastuneet $(n=13)$ kuin myös läheiset $(n=13)$ kertoivat erittäin kattavasti kokemuksistaan, ja kertomuksista löytyy runsaasti vastauksia tutkimuskysymyksiin - myös niin, että samantyyliset huomiot toistuivat eri haastateltavien tarinoissa, eli aineistossa saavutettiin saturoitumista. Analysointi tehtiin yhteistyössä kolmen tutkijan kesken. Alkuvaiheen analysoinnin, eli litteroinnin, aineistoon tutustumisen, ilmaisujen poimimisen ja niiden teemoittelun, toteutti ensimmäinen kirjoittaja, ja tarinatyyppien esille hahmottumisen vaiheessa analyysiä jatkettiin kolmen tutkijan yhteistyönä. Tässä vaiheessa palattiin alkuperäisilmaisuihin ja teemoitteluun sekä muodostettiin yhteistä ymmärrystä siitä, miten tarinatyyppejä kuvataan.

Tulosten yleistettävyyttä voi heikentää rekrytoinnin pitkä kesto ja osallistujien valikoituminen. Osallistujien rekrytointi tutkimukseen kesti lähes vuoden. Syynä rekrytoinnin melko pitkään kestoon oli se, että työikäisenä muistisairauteen sairastuvia on melko vähän, ja lisäksi diagnoosin saamiseen liittyy kuormitusta, minkä vuoksi läheskään kaikki sairastuneet eivät ole valmiita osallistumaan tutkimukseen ja jakamaan sairastumiseen liittyviä kokemuksiaan. Tämän vuoksi tutkimukseen osallistujien joukko on valikoitunutta, painottuen naisiin ja henkilöihin, jotka esimerkiksi luonteensa tai työhistoriansa takia ovat kiinnostuneet keskustelusta ja sosiaalisesta kanssakäymisestä. Lisäksi etenevän muistisairauden aiheuttajat eivät tutkimukseen osallistujilla täysin kata tyypillisimpiä alle 65-vuotiaiden sairauksia. Esimerkiksi vaskulaarista tai alkoholin käytöstä johtuvaa muistisairautta sairastavia henkilöitä ei ollut osallistujien joukossa lainkaan, ja otsa-ohimolohkorappeumaa sairastavia henkilöitä oli vain yksi, vaikka alle 65-vuotiaana sairastuneilla edellä mainitut sairaudet aiheuttavat yhteensä lähes kolmanneksen muistisairauksista (Hayo 2015). Tutkimuksessa ei pyritä tulosten yleistettävyyteen tilastollisessa mielessä, vaan tarkoituksena on tuottaa jäsennyksiä ja tulkintoja tutkittavasta ilmiöstä (Saarenheimo 1997). Tutkimustuloksia hyödyntävän on hyvä huomioida, että muistisairautta sairastavien kokemukset voivat olla vielä tässä artikkelissa esitettyä moninaisempia. 


\section{Menetelmät}

Tutkimusaineisto on analysoitu soveltaen narratiivisen tutkimuksen menetelmiä. Kertomusten analyysille ei ole olemassa vakiintunutta metodia, joka etenisi samanlaisena eri aineistoissa, vaan analyysimenetelmäksi valitaan aineistoon sopiva analyyttinen väline, jota sovelletaan tutkimuskysymysten mukaisesti. Kertomuksiin vaikuttavat kertojan arvomaailma, hänen sosiaaliset suhteensa, yhteisöt, joihin hän kuuluu, sekä kertomuksen kertomisen aika ja paikka. Kertomukset ovat tilanteisiin sidottuja,ja kertomusten rakentumisessa tärkeää on vuorovaikutus ja konteksti sekä tapahtumien aikajärjestys. Lisäksi kertomuksien avulla osoitetaan epäjärjestystä ja elämänmuutosten tuottamia selviytymishaasteita. Tärkeä elementti on myös kuvaus siitä, millaista on elää kertomuksessa esitetyn epäjärjestyksen läpi, millaisia kehitysprosesseja kertomukseen liittyy ja millainen kertomuksen suhde on kulttuurisiin mallitarinoihin. (Hyvärinen 2010.)

Litteroidusta haastatteluaineistosta haettiin tutkimustehtävän mukaisesti ilmaisuja tai osatarinoita, joilla haastateltava kuvasi sairastumisen aiheuttamia muutoksia elämäntilanteessaan, suhtautumista ja sopeutumista sairauteen, sairaudelle annettuja merkityksiä sekä sitä, miten haastateltava suhteutti kertomuksensa ajallisesti tähän hetkeen ja tulevaan. Osatarinoilla tarkoitetaan yksittäisiä ilmaisuja laajempia, samaa aihetta käsitteleviä kokonaisuuksia, kuten keskustelukatkelmaa tai useampia samaan aiheeseen liittyviä ilmaisuja haastattelun eri kohdista, jotka kuitenkin edustavat esiteltyjen tarinatyyppien mukaista tulkintaa muistisairauden kanssa elämisestä. Kokemusten monipuolisuutta pyrittiin tavoittamaan sillä, että aineistosta huomioitiin toistuvasti kerrottuja asioita, yllättäviä ja vahvoja sekä myös eriäviä ja hiljaisempia kokemuksia. Alkuperäisilmaisuja haettaessa aineistosta hahmottui seitsemän sairastumisen vaiheeseen liittyvää, yhdistävää teemaa: ensimmäiset muutokset ja huolen herää- minen, tutkimukset ja diagnoosi, suoriutuminen ja suhtautuminen, arjen aktiivisuuden merkitys, parisuhde ja muut ihmiset ympärillä, muuttuneeseen elämäntilanteeseen sopeutuminen sekä ajatukset tulevaisuudesta ja sairauden vaikutuksesta. Keskeiset ilmaisut ja osatarinat koottiin yhdistävien teemojen mukaisiksi kokonaisuuksiksi erikseen sairastuneiden ja läheisten haastatteluista. Analyysin painopiste pidettiin sairastuneen kokemuksien kuvauksissa. Läheisten kertomuksia peilattiin sairastuneen tarinaan osallistujapareittain, jolloin oli mahdollista tavoittaa yhtäläisyyksiä, ristiriitoja sekä tarinoiden keskinäistä resonointia. Teemoitellusta aiheistosta hahmottui kolme toisistaan eroavaa tarinatyyppiä, joiden sisäisiä merkityksiä ja yhdistäviä tekijöitä on kuvattu taulukossa 1. Hänninen (1999) on käyttänyt käsitettä tarinatyyppi kuvatessaan elämänmuutoksia tarinallisesta näkökulmasta ja jäsentäessään erilaisia merkityksenantotapoja. Kukaan haastatteluun osallistuneista ei edustanut pelkästään yhtä kertomisen tapaa, eli tarinatyypit ovat muodostuneet eri osallistujien osakertomuksista.

\section{Tulokset}

Sairastuneiden ja heidän läheistensä kokemuksista erottui kolme tarinatyyppiä, joissa tulevat esille uuteen elämäntilanteeseen liittyvät omanlaiset toiminta- ja suhtautumistavat sekä niitä ohjaavat arvot ja merkitykset. Tarinoiden välillä on havaittavissa kolme keskeistä erottavaa tekijää. Ensinnäkin eroja esiintyi sairastuneen suhtautumisessa aikaan, erityisesti tulevaisuuteen. Toiseksi eroja löytyi omissa koetuissa mahdollisuuksissa vaikuttaa niin sairauden etenemiseen kuin omaan elämäntilanteeseenkin. Kolmas tarinoiden pohjavireen ero on sairastuneiden ja läheisten näkemyksien samankaltaisuus tai eroavuus. Tarinatyypit on nimetty kaaoksen, irtautumisen ja aktiivisuuden tarinaksi (taulukko 1). 


\begin{tabular}{|c|c|c|c|}
\hline 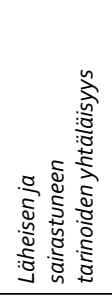 & 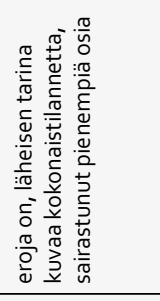 & 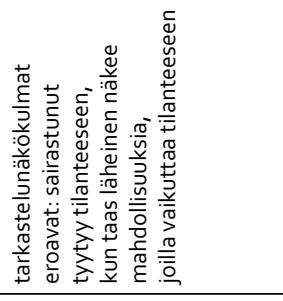 & 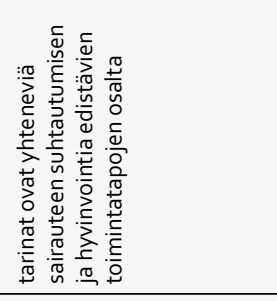 \\
\hline 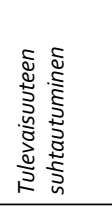 & 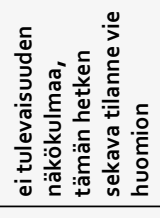 & 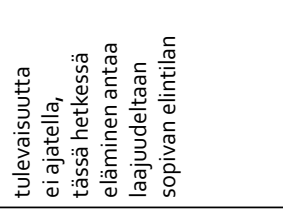 & 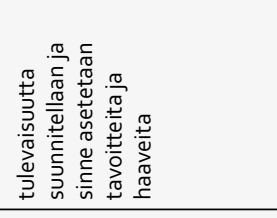 \\
\hline 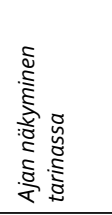 & 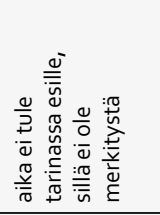 & 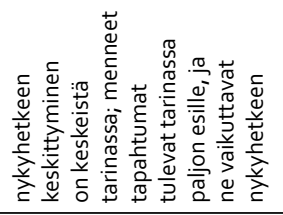 & 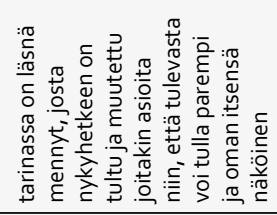 \\
\hline 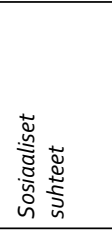 & 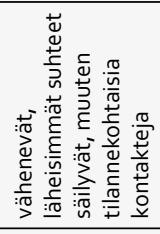 & 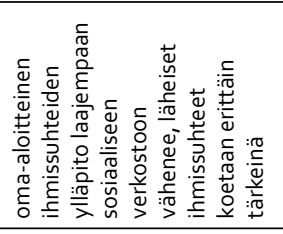 & 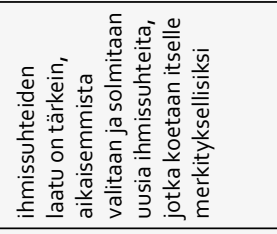 \\
\hline 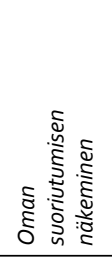 & 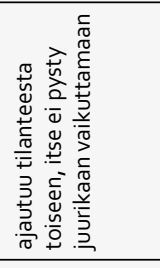 & 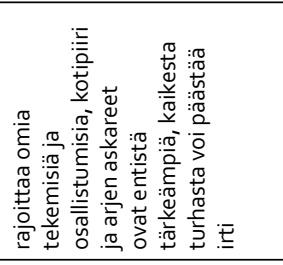 & 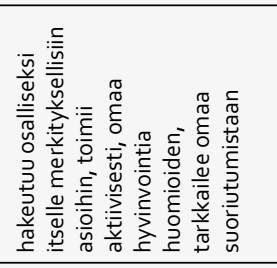 \\
\hline 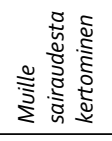 & $\begin{array}{l}\frac{\pi}{0} \\
\frac{0}{\bar{\nu}} \\
\frac{\bar{\omega}}{\bar{\omega}} \\
\end{array}$ & 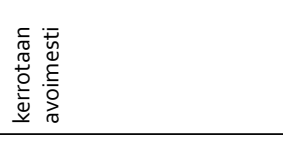 & 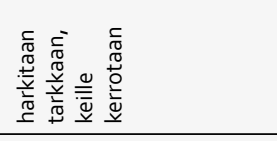 \\
\hline 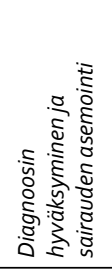 & 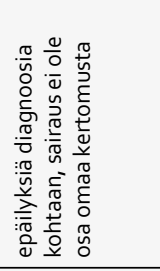 & 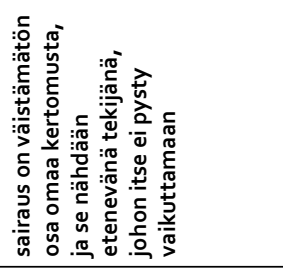 & 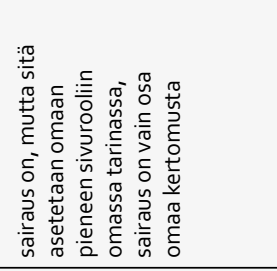 \\
\hline 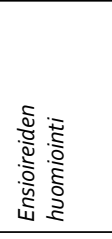 & 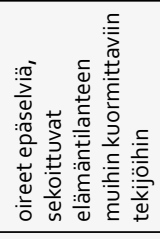 & 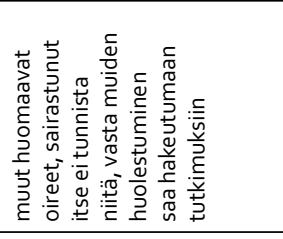 & 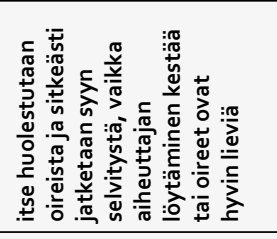 \\
\hline & 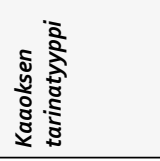 & 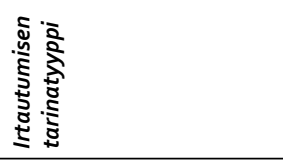 & 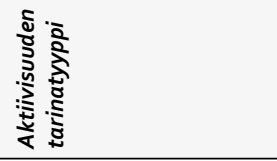 \\
\hline
\end{tabular}


Yhteistä kaikille sairastumisen tarinoille näyttivät olevan sairauden moninaiset ensioireet, jotka vaikuttivat eri tavoin tiedonkäsittelytoimintoihin sekä sitä kautta arjessa suoriutumiseen ja saivat aikaan tutkimuksiin hakeutumisen. Ensimmäiset muutokset tulivat esille esimerkiksi työstressin lisääntymisenä,jaksamisen ongelmina, unettomuutena, masentuneisuutena, uudenlaisten toimintatapojen omaksumisen hankaluutena, tietokoneella toimimisen ongelmina, oman talouden hallinnan vaikeutena, sanojen tai nimien unohteluna, aikaisemmin käydyn keskustelun lopputuloksen unohtamisena tai hitauden ja väsymyksen lisääntymisen kokemuksena. Se, miten sairastuneet itse suhtautuivat ensioireisiin ja kuinka he toimivat tunnistettuaan muutokset, sekä se, miten yllättävänä diagnoosi koettiin ja miten sairauden toteamisen jälkeen toimittiin, vaihteli eri tarinatyypeissä. Seuraavaksi esitellään eri tarinatyypit keskeisine ominaispiirteineen.

\section{Kaaoksen tarinatyyppi}

Kaaoksen tarinatyypissä keskeisinä piirteinä nousivat esille eri tilanteisiin liittyvä epävarmuus ja ennakoimattomuus sekä monenlaiset muutoksia aiheuttavat tekijät. Sairastuneiden kuvauksissa ensioireiden kerrottiin olleen epäselviä, ja tuon ajanjakson kertomisessa keskityttiin sairauden oireiden sijaan pikemminkin muihin elämään kaaosmaisuutta tuoneisiin tekijöihin. Tällaisia olivat esimerkiksi ajanjaksoon osunut muutto, perheenjäsenen raskashoitoinen ja vakava sairaus tai työyhteisössä ilmenneet ongelmat, jotka heijastuivat ja kuormittivat myös itseä. Vasta muiden huolestuminen sai hakeutumaan tutkimuksiin, ja kesto ensioireista diagnoosin saamiseen vei joidenkin kohdalla hyvinkin pitkään. Diagnoosin saaminen ei selkeyttänyt tilannetta, jos sairaus jäi etäiseksi sen vuoksi, että elämäntilanteen muutosten ja vaatimusten vuoksi sen prosessointiin ei ehditty keskittyä tai sitä ei hyväksytty osaksi omaa tilannetta. Omasta sairaudesta ei haluttu myöskään kertoa muille ihmisille; vain lähim- mät tiesivät diagnoosista. Jos diagnoosiin liittyi epävarmuutta, saattoi kokemus omasta sairaudesta jäädä epäselväksi. Epävarmuus sairauden luonteesta aiheuttaa sen, että tarinalla ei ole varsinaista selväpiirteistä alkua tai siirtymää alusta (diagnoosi) seuraavaan vaiheeseen (sairastaminen), vaan sairastunut jää jossain määrin kellumaan näiden vaiheiden väliin.

\section{Ensin sanottiin, että sulla on Alzheimerin tauti, jolloin mä olin aivan kaubistunut. Sitten otettiin neulanäyte, ja ne sano siitä, että ei todellakaan ole Alzheimerin tauti, eikä ole lähelläkään. Sitten mä olin, että huh, buh. Sitten taas vähän tutkittiin, ja kyllä onkin. Että lääkärit oli eri mieltä. Ja kun oon väbän tämmöinen epäilevä luonne, niin en mä nyt ihan varma vielä oo. (sairastunut)}

Sairastuneen suoriutumisessa tapahtuneet muutokset aiheuttivat sekavia tilanteita. Työelämästä poisjääminen ja muuttunut elämänrytmi monien muiden muutosten keskellä oli uusi tilanne. Taloudellisten ongelmien kasautuminen, sairauden etenemiseen liittyvät pelot, parisuhteeseen liittyvät haasteet tai nukkumisen ongelmat kuormittivat, jolloin myös muistisairauden oireet lisääntyivät ja tunne elämänhallinnasta väheni. Omaan olotilaan saattoi liittyä epävarmuutta, itseluottamuksen vähenemistä, päivän tekemisten suunnittelun haasteita tai liian monen asian yhtä aikaa tekemistä. Tällaiset muutokset aiheuttivat sekavaa oloa ja varmistelun tarvetta, ja välillä olotilan kuvattiin olevan "semmoista leijumista". Tarinassa on myös tyypillisesti mukana vähän toimijoita. Elämänpiiri on tapahtuneiden muutosten takia kaventunut. Lisäksi tarinalle on tyypillistä tietynlainen pysähtyneisyys; ajan kuluminen ei tuota merkittäviä muutoksia tilanteeseen, eikä sen kulumista juurikaan kuvata. Sitäkin enemmän tarinoissa on mukana muutoksia aiheuttaneita tapahtumia sekä odotusta, joskaan aina ei käy selväksi, mitä odotetaan.

Tämän tarinatyypin käännekohdaksi, muihin osiin vaikuttavaksi tekijäksi, näyttäisi muo- 
dostuvan tulevaisuuteen suhtautuminen. Sairastuneiden tarinoissa tuli esille kokemus siitä, ettei itse pysty vaikuttamaan tilanteeseen vaan ikään kuin kulkeutuu tilanteesta toiseen. Tämä havainto vaikutti myös tulevaisuuden ajatteluun: tulevaisuutta ei juurikaan suunniteltu, koska käytettävissä oleva energia kului arjen haasteista selviämiseen ja tilanteeseen johtaneiden menneiden asioiden tarkasteluun. Ja koska toiminnalla ei ole suuntaa, ei tarinalla myöskään ole loppua, jotakin tapahtumaa tai tavoitetta tai "välitilinpäätöstä" (closure, ks. Pietilä ym. 2018), jota kohden kertoja katsoisi olevansa matkalla ja joka siten tuottaisi odotushorisonttia ja rytmiä kerrontaan. Kaaoksen tarinalle on kaiken kaikkiaan luonteenomaista jäsentymättömyys ajallisesti ja tarinan vaiheiden osalta.

Sairastuneiden ja läheisten tarinoissa esiintyi selviä eroja. Läheiset huomioivat sairastuneen tilanteessa tapahtuneita muutoksia etäämmältä ja kattavammin kuin sairastuneet itse. Sairastuneiden haastattelut sisälsivät yksittäisiä osatarinoita, joiden välinen yhteys saattoi jäädä epäselväksi, tai tarinat limittyivät kokonaistilanteeseen vasta läheisen haastattelun jälkeen, kun kokonaiskuva elämäntilanteesta oli hahmottunut. Läheisillä oli vastuu laajemmasta tilannekuvasta.

Tässä vaiheessa on nïn hirveen vaikee yksittäisiä pieniä nyansseja käsittää, että liittyykö se Alzheimerin tautiin vai onko se johdannaista mitä on sitten puolison sairastumisesta. Että siitä lääkkeen tehon vaikutuksesta tai onko se paikallaan junnaava vai meneekö se näin ja näin. Kaikki vaikuttaa kaikkeen... huolenpitovastuu on mulla ja siskolla lisääntynyt niin kuin ylipäätään tekeminen on lisääntynyt. Että ennen pääsi helpommalla, vaikka isä nyt on sairastanut pitkään, mutta tiesi että siellä on toinen, joka pystyy suoriutumaan. Mut sit kun sen suoritustaso rupee beikkenemään, niin ei sitä voi olla noteeraamatta ite, että sitten on autettava enemmän. Oli se sitten fyysistä tai asianhoidollista tai mitä tahansa, niin kumminkin. (läheinen)
Tässä tarinatyypissä läheisen tilanne kuvautuu kuormittavana, epäselvät ja arvaamattomat tilanteet olivat yleisiä ja sairastuneiden kyky huolehtia omista asioista oli heikentynyt. Samanaikaisesti avuntarpeiden tunnistaminen ja myös avun pyytäminen saattoi olla haastavaa. Tämä sai aikaan sen, että läheisten rooli korostui niin muutosten huomioimisessa kuin huolenpitämisessäkin ja tulevaisuuden suunnittelussa.

\section{Irtautumisen tarinatyyppi}

Irtautumisen tarinassa ensioireet ja diagnoosin saaminen tulivat sairastuneiden kertomuksissa esille hiukan etäisenä prosessina, jossa usein vasta muiden huolestuminen sai hakeutumaan tutkimuksiin. Diagnoosin saamisen jälkeen näyttäisi tapahtuvan irtautumisen tarinalle omaleimainen käännekohta. Käännekohdassa muistisairaus todetaan väistämättömäksi osaksi omaa kertomusta ja havaitaan, että etenevä sairaus tulee muuttamaan elämää kohti ei-toivottua suuntaa, johon itse ei pysty vaikuttamaan. Tämä käännekohta vaikuttaa tarinan muihin osiin.

Äitihän ei myöntänyt ikinä [omaa muistiongelmaansa], et mää osaan sitten myöntää ne asiat toisella lailla, mutta äiti ei sitä osannut. (sairastunut)

Diagnoosista kerrottiin avoimesti muille, niin lähipiirille kuin myös laajemmin muillekin ihmisille, joita asia jollain tavoin koski. Tämä avoimuus sairaudesta kertomisessa oli erilaista kuin muissa tarinatyypeissä ja saattoi johtua siitä, että sairaus hyväksyttiin ja nähtiin väistämättömänä osana omaa elämää.

Haastattelija: Ootko sä kertonut sairaudesta, vaikka jollekin läheiselle tai ystäville?

Sairastunut: Joo kyllä kaikki tietää. Mä oon avoin siinä.

Haastattelija: Mites ne on subtautunut? 
Sairastunut: No ei ne, mitäs ne. Ottaa osaa tietysti vähän, ja minä oon sen sanonut kaikille, että mun mielestä tää on geenikysymys, että se on pitkälti sieltä, minkäs sille voi, väärään perheeseen on syntynyt (nauraa).

Tarinatyypille oli tyypillistä, että sairastunut rajoitti omia tekemisiään ja osallistumisiaan kotipiirin ulkopuolella arjen askareiden muodostuessa tärkeäksi osaksi elämää. Kaikesta ylimääräiseksi koetusta haluttiin päästää irti, ja esimerkiksi kiireisestä, stressaavasta työelämästä poisjääminen koettiin helpottavana. Helpotusta tuotti myös autoilun lopettaminen, jos ei ollut ikinä erityisemmin pitänyt ajamisesta. Aikaorientaatiossa sairastuneet keskittyivät menneeseen ja nykyhetkeen. Aikaisemman elämän ja sen jatkuvuuden merkitys oli suuri. Asioista, jotka olivat olleet itselle aikaisemmin merkityksellisiä, kerrottiin paljon, ja ne kuvattiin edelleen osana elämää, vaikka toimintatavat olisivatkin muuttuneet. Sairastuneiden halu haastaa itseään vaikeammista asioista suoriutumiseen vaikutti kadonneen; he tyytyivät vähempään ja rajallisempaan toimintaan kuin aikaisemmin. Tämä saattoi näkyä esimerkiksi television katselun, alkoholin käytön tai tietokoneen käytön lisääntymisenä, eli toiminta siirtyi enemmän sosiaalisesti passiivisiin asioihin, joissa sosiaalisen vuorovaikutuksen elementti ja muut ihmiset ovat sivussa. Näiden toimintojen lisääntymisestä sairastuneet itse kertoivat vähemmän, ja asiat tulivat enemmän esille läheisten kertomuksissa.

Mä oon tullut sillä tavalla araksi lähteä vieraalle alueelle, niin kuin kävelyä tarkoitan. Mutta semmoisia paikkoja kävelen, että tiedän, että osaan tulla kotiin. Aika lähellä, mutta ei sillä niin väliä ole. Kun pääsen sinne ulos, happea hengittämään. (sairastunut)

Tulevaisuus sai irtautumisen tarinoissa hyvin vähän huomiota. Sairastuneet kertoivat usein seuranneensa lähipiirissään jonkun iäkkäämmän henkilön muistisairauden etenemistä, ja joillakin oli myös kokemuksia vanhemman tai sisaruksen varhaisemmalla iällä alkaneesta muistisairaudesta. Toisten muistisairauksien etenemistä kuvattaessa sairastuneiden huomio kiinnittyi sairauden loppuvaiheeseen, toimintojen heikkenemiseen ja muiden avun varassa elämiseen. Sairastuneiden omat ennakkokäsitykset sairauden etenemisestä näyttivät johtavan siihen, että he eivät halunneet ajatella ja suunnitella omaa tulevaisuuttaan, vaan tässä hetkessä eläminen antoi heille laajuudeltaan sopivan elintilan:

Mitään muuta [kuin kuolemaa] mä en pelkää, enkä mä tiedä tarviiko sitäkään sen enempää pelätä. Mieluummin kuolisi äkkiä sitten kun se aika tulee, eikä jäis kitumaan tonne sängynpohjalle. Läbinnä se on se pelko. (sairastunut)

Irtautumisen tarinassa esiintyi muita tarinatyyppejä selvemmin ero sairastuneiden ja heidän läheistensä kokemusten välillä. Kuvaukset sairastuneen aktiivisuudesta ja osallistumisesta olivat erilaiset, samoin näkemykset vaikutusmahdollisuuksista hyvinvointiin erosivat. Sairastuneiden tarinoissa oltiin pääasiassa tyytyväisiä siihen toimintaan, jota senhetkisessä arjessa tehtiin, kun taas läheiset kuvasivat pyrkimyksiään aktivoida sairastunutta:

\section{Pitäis varmaan pohtia tässä sitä kuntoutus- ta, että millä tavalla hän itse voisi, kun mitä mä oon ymmärtänyt, että jollain tavalla pys- tyy itsekin aktivoida sitä aivotoimintaansa, erilaisia muistipelejä ja muuta. Voisi yrittää vaikuttaa sen hidastumiseen... et nä̈̈ on mun ajatukset, mutta sitten se bänen oma, mää en pysty siiben kerta hän ei halua. (läheinen)}

Läheisten kertomuksista tuli esille lisääntynyttä vastuunkantoa arjen asioista ja ajoittaista kuormittumista, esimerkiksi jos läheisen piti opetella itselleen uusia kotitöitä tai muistaa ja hallita arjen kokonaistilannetta myös sairastuneen puolesta. Läheiset kuvasivat neuvottomuutta muuttuneiden tilanteiden ratkaisemisessa, jos 
he eivät tienneet, millaisia keinoja tilanteessa voisi kokeilla tai miten omia toimintatapoja voisi muuttaa.

\section{Aktiivisuuden tarinatyyppi}

Aktiivisuuden tarinatyypin käännekohta tulee esille jo aivan tarinan alussa, ensioireiden huomioimisessa ja niihin suhtautumisessa. Sairastunut havaitsi itse pieniä, toistuvia muutoksia ja huolestui niistä. Vaikka muutosten aiheuttajan löytäminen ja tutkimukset kestivät pitkäänkin, hän vei sitkeästi asiaa eteenpäin siihen asti, että muutosten varsinainen aiheuttaja löytyi. Aktiivisuuden tarinoihin sisältyi monia toimijoita ja aktiivista toimintaa. Tämä tuli esille myös sairauden ensioireista ja tutkimuksista kerrottaessa tarinoiden monipuolisuutena, tapahtumien ja niihin liittyneiden ihmisten esille tuomisena ja yhteyksien tarkasteluna.

Diagnoosin saaminen oli järkytys, kuten kaikissa muissakin tarinatyypeissä, mutta diagnoosin saamisen jälkeen sairastuneet tyypillisesti selvittivät itse aktiivisesti käytännön asioita ja valitsivat toimintatavat. Esimerkiksi eläkejärjestelyjä selvitettiin Kelasta tai järjesteltiin osa-aikatyöhön siirtymistä. Yleisesti ottaen sairauden olemassaolo hyväksyttiin, mutta se asetettiin tietoisesti pieneen sivurooliin omassa tarinassa, ja tätä ajattelutapaa kuvastaa myös sairaudesta muille kertominen. Ihmiset, joille sairaudesta kerrottiin, mietittiin tarkasti, koska muiden ihmisten suhtautumisen itseen ei haluttu muuttuvan. Sairauden ei nähty vaikuttavan omaan olotilaan tai toimintaan tässä kohdin merkittävästi. Tosin heti diagnoosin saamisen jälkeisessä shokkitilassa tätä harkintaa ei välttämättä pystytty tekemään, ja nopeaa sairaudesta kertomista työnantajalle tai työyhteisölle saatettiin jälkikäteen katua, jos se oli vaikeuttanut työssä jatkamista:

Tän diagnoosin jälkeen, jälkeenpäin oon aatellu ja oon psykologinkin kanssa pubunut, että olis ollut tosi tärkeetä, että se lääkäri ois ymmärtänyt mua ja yrittänyt suojella mun psyykettä. Että mä en ollu siinä kohtaa siinä mielentilassa, että mun olis kannattanut töibin mennä. Mun olis kannattanut olla se kaks viikkoo tai viis viikkoo sairaslomalla ja sen jälkeen sitten mä oisin tiennyt, että pamautanks mä töissä tän tiedon kaikille vai en. Että en mä osannut suojella ittee siinä kohdin. (sairastunut)

Aktiivisuuden tarinassa sairauden aiheuttamia elämänmuutoksia tarkasteltiin monipuolisesti, ja sairastuneet suunnittelivat itse, millaisia asioita haluavat tehdä. He myös pohtivat omia arvojaan ja itselleen tärkeitä asioita. Tilanne nähtiin uutena elämänvaiheena, johon sisältyi aikaisemmasta eroavia asioita, kuten työstä poisjäämisen mahdollistama osallistuminen "täysillä" itseä kiinnostaviin harrastuksiin tai elämässä aikaisemmin kohdattujen psyykkisesti kuormittavien asioiden työstäminen psykologikäyntien avulla. Sairautta ja omaa hyvinvointia huomioitiin valinnoissa; esimerkiksi arjen kuormittavuutta tarkasteltiin uudella tavalla ja omaa suoriutumista arvioitiin hyvin tarkasti. Työ tuli esille monin tavoin sairastuneiden kertomuksissa. He kertoivat omasta työhistoriastaan ja pohtivat omaa työkykyään, työn merkityksellisyyttä ja työn vaatimuksia sekä sitä, miten työpaikoilla suhtauduttiin sairastumiseen. Muistisairausdiagnoosiin oli suhtauduttu työpaikoilla vaihtelevasti. Sairastunut saattoi saada työkavereiltaan sekä esimieheltään tukea, ja työtä muunnettiin joustavasti esimerkiksi osa-aikatyöksi, kun taas jossain tilanteessa työnantaja ensin ohjasi työntekijää irtisanoutumaan, ja kun työntekijä ei tähän suostunut, hänen työkykyään testattiin uudelleen sijoittamalla hänet haastavampiin tehtäviin. Aktiivinen toimintatapa näyttäytyi tällaisessa tilanteessa esimerkiksi oman edun puolustamisena työpaikalla tai yhteydenottona muistiliiton lakimieheen. Sairastuneet hyödynsivät laajasti omaa verkostoaan ja eri toimijoita uuteen tilanteeseen sopeutumisessa. Myös oma asennoituminen oli merkityksellistä elämänmuutoksessa: 
Mä oon aina ajatellut, että kun elämässä on tullut jotain, niin mä oon löytänyt niitä positiivisia asioita. Että jos tulee tämmöinen [sairaus], niin sitten pitää löytää jotain positiivista. Mulla se on tällä hetkellä tuo osatyökyvyttömyyseläke. Sitäkin voi vähän vitsakkelisti ajatella - ihanaa olla vähän töissä, vaikka on vähän hölmö. (sairastunut)

Ajallisesti tarinassa on läsnä mennyt, nykyhetki ja tuleva. Aiempia päätöksiä on suunnattu siten, että tästä hetkestä ja tulevasta voisi tulla parempi. Tulevaisuuteen liittyvät tavoitteet koskivat paljolti omaa ja läheisten hyvinvointia ja itsensä näköisen elämän elämistä. Aktiivisuuden tarinassa dementiaan, eli sairauden loppuvaiheeseen, ja sairauden etenemiseen liitettyjä yleisiä olettamuksia ja kauhukuvia vastustettiin. Sairastuneet näkivät, että pystyvät itse vaikuttamaan moniin asioihin ja hämmästelivät sitä, miten ympärillä yleisesti sairauteen suhtaudutaan. Toki he myös pohtivat oman toimintakykynsä rajoja sekä sairauden etenemiseen liittyviä epävarmuuksia. Tulevaisuutta huomioitiin eri tavoin; sairastuneilla oli harrastuksiin, matkustamiseen ja työelämään liittyviä tulevaisuuden suunnitelmia. Työelämään liittyvät suunnitelmat saattoivat koskea niin eläkkeelle jäämisestä haaveilemista kuin myös alanvaihtoa työhön, josta oli pitkään haaveillut:

Ois kiva jo tehdä muutakin [työtä], se ois sitä mun vabouusaluetta ja siitä todennäköisesti maksettais enemmän ja se vois olla jopa kivempaakin. Mutta se tuntuu tavallaan aika järjettömältäkin tässä kobtaa haaveilla sitä, kun tarjoillaan tietyllä tapaa tämmöistä, että hommaa se hoivakotipaikka. Sitten sitä kokee ittensä, että ottaako mut joku töibin ja pystynks mä tekeen jotain töitä, ja teenkö mä jotenkin väärin, jos mä en kerro tätä diagnoosia? Pitäiskö mun sitten vaan tavallaan solabtaa siiben rooliin, joka mulle on tarjottu, eli pistä paperit kuntoon ja kaikki ylimääräinen homma pois, kun kohta kuolet kumminkin, taval- laan kun mikään ei näytä nyt siltä, että se ois tässä kohtaa realismia. (sairastunut)

Aktiivisuuden tarinassa sairastuneiden ja läheisten kertomukset olivat keskenään hyvin samankaltaisia, ja elämäntilanteen toimintatavat ja sairaudelle annetut merkitykset olivat yhteneväisiä. Molempien kertomuksissa tuli esille kokemus siitä, että sairastunut pystyy itse monin tavoin vaikuttamaan elämän kulkuunsa, kuten siihen, jatkaako hän töissä, mitä harrastaa, kuinka huolehtii omasta hyvinvoinnistaan sekä miten toimii omaa terveyttään, erityisesti aivoterveyttään, edistävästi. Läheiset osoittivat tukevansa sairastunutta hänen valinnoissaan esimerkiksi selvittämällä yhdessä hoitokeinoja, yhteisillä harrastuksilla ja huolehtimalla hyvinvoinnista. Läheisiltä saatu tunneperäinen tuki, yhteenkuuluvuudentunne ja läheisyys näytti korostuvan tässä tarinatyypissä. Huumori tuli esille yhteiselämän voimavarana, ja myös sairaudesta saatettiin lähimpien kesken vitsailla ja välillä"heittää rankkaakin huumoria". Yhteisen ajan kuvattiin lisääntyneen sairastumisen jälkeen, ja yhteinen tekeminen oli usein sisällöltään hyvinvointia vahvistavaa, ollen samalla sairautta vastaan kamppailua:

Odotetaan ja katsotaan, aika näyttää. Yrittää nyt tasapainoista elämää, ei rupee kovin puritaaniksi. Saa olla paheita, mutta järki päässä, vähän niin kuin Arvo Ylppö, että kaikkee vähän ja tasapaino olemisessa... mä koetan myöskin omaa roolia vähän niin kuin himmatakin, että musta ei välttämättä tuu tukipilaria. Joskus on hyväksi se, että mielipiteitä ja kannanottoja tulee jostain muualtakin, jolla on auktoriteettiä, kun sitten taas mulla puolisona. Mä oon väbän niin kuin huonekalu (nauraa) että mä en missään vaibeessa ala liian aikaisessa vaibeessa hoitamaan tai mitään. (läheinen)

Läheiset olivat pohtineet omaa rooliaan, ja sairauteen rauhallisesti suhtautuminen ja tule- 
vaisuuden "kauhukuvien maalaamisen" välttäminen nähtiin tärkeänä. Läheisen tuki oli sitä, että hän ei korostanut sairautta vaan ennemminkin asetti sen taustatekijäksi ja kiinnitti huomiota muuten hyvään arkeen ja elämiseen.

\section{Pohdinta}

Työikäisenä muistisairauteen sairastuminen muuttaa radikaalilla tavalla oletettua elämänkulkua ja aiheuttaa muutoksia esimerkiksi sairastuneen pystyvyyteen, identiteettiin ja sosiaalisiin suhteisiin (mm. Greenwood \& Smith 2016; Johannessen ym. 2018). Tarinan kertominen elämän muutostilanteessa mahdollistaa muutoksiin liittyvien prosessien pohtimisen sekä auttaa rakentamaan uudenlaista käsitystä itsestä (Hänninen 1996; Frank 2013). Tähän tutkimukseen osallistuneiden kertomat kokemukset ja niistä muodostuvat tarinatyypit olivat hyvin vaihtelevia ja yksilöllisiä. Kaaoksen tarinatyyppiä leimasi eri tilanteisiin liittyvä epävarmuus ja sekavuus, joka aiheutui sairauden monista oireista mutta myös elämäntilanteeseen liittyvistä epäselvyyksistä. Hännisen (1999) tarinallisen kiertokulun teorian näkökulmasta kaaoksen tarinassa sairastuneen sisäinen tarina tulee esiin vain vähän ja pirstaleisesti, lähinnä situaation eli elämäntilanteen kuvaamisen kautta. Irtautumisen tarinatyypissä keskityttiin tässä hetkessä elämiseen ja haluttiin viettää rauhallista, omantahtista elämää. Sairaus jätettiin taustalle. Irtautumisen tarinassa sisäinen tarina keskittyy ennen muuta toimintaan, joka liittyy totuttuun elämänrytmiin, huomion kiinnittyessä itselle mielekkääseen tekemiseen ja kuormittumisen välttämiseen. Aktiivisuuden tarinatyypissä elämää suunniteltiin eteenpäin ja aktiivisen toiminnan kautta haluttiin vaikuttaa sekä sairauteen, omaan hyvinvointiin laajemmin että yleisemmin omaan elämänkulkuun. Aktiivisuuden tarina sisälsi paljon merkitysten pohdintaa, ja kerronnassa tulivat esille kaikki sisäisen tarinan ulottuvuu- det. Situaation näkökulmasta elämäntilannetta huomioitiin kokonaisuutena ja sairauden vaikutuksia suhteutettiin siihen. Omassa toiminnassa huomioitiin sairauden merkitys, oma kykeneminen sekä itselle merkitykselliset asiat. Sosiaalisen tietovarannon ulottuvuuteen kohdistuvia muistisairauksiin liittyviä kulttuurisia olettamuksia kyseenalaistettiin, ja esimerkiksi omasta sairaudesta muille kertomista harkittiin tarkoin. Kerrotusta tarinasta muodostui jäsennetty kokonaisuus, johon myös haastatteluun osallistuminen kuului - omien kokemusten kertominen auttoi jäsentämään omaa tilannetta. Elämäntarinan uudelleen rakentaminen (narrative recontruction, Williams 1984) tapahtuu muistisairauteen sairastumisen jälkeen ihmisillä eri tavoin, ja siihen liittyviä erilaisia prosesseja voidaan tunnistaa tarinatyypeistä.

Tässä tutkimuksessa esitettyjen tarinatyyppien ja Frankin (2013) sairastamiseen liittyvien kolmen kulttuurisen mallitarinan väliltä löytyy yhteneväisyyksiä. Vahvin yhtäläisyys on kaaoksen tarinoiden välillä (chaos narrative): muistisairaus ja elämäntilanteeseen osuneet muut muutokset ovat muuttaneet elämää hallitsemattomalla tavalla, eikä sairastuneella ole keinoja päästä tilanteesta ulos. Myös irtautumisen tarinassa on havaittavissa kaaostarinan piirteitä, sillä siinäkin sairaus nähdään väistämättömänä tilanteena, jossa tulevaisuus on synkkä ja omat tilanteen kontrollointi- ja vaikutusmahdollisuudet ovat pienet. Kaaostarinaan verrattuna irtautumisen tarina on kuitenkin tarinatyyppinä eheämpi ja jäsentyneempi. Aktiivisuuden tarinassa on samoja elementtejä kuin palauttavassa (restitution narrative) ja etsinnän (quest narrative) tarinassa. Siinä orientaatio on tulevaisuuden aktiivisessa suunnittelussa ja omaa hyvinvointia tukevassa toiminnassa. Yhtymäkohtana etsinnän tarinaan on sairauden mukanaan tuomien myönteisten mahdollisuuksien näkeminen sekä pyrkimys sairauden hyväksymiseen. Aktiivisuuden tarina ei kuitenkaan edusta palauttamisen tarinatyyppiä, sillä haastateltavat olivat hyvin tietoisia muistisairauden vääjää- 
mättömästä etenemisestä; paluuta entiseen ei siis ole. Tämä muistisairauden luonne rajoitti myös etsinnän tarinaan yleensä sisältyviä uusia aloituksia elämässä: uusia asioita haluttiin kokea mutta sairauden asettamissa raameissa.

Tässä tutkimuksessa havaittuja tarinatyyppejä voidaan tarkastella myös siitä näkökulmasta, miten ne kytkeytyvät eri elämänvaiheita koskeviin kulttuurisiin mallitarinoihin. Kaaoksen tarinassa epäselvällä elämänvaiheella ei ole suuntaa, eikä sitä voida ankkuroida kulttuurisiin mallitarinoihin elämänvaiheista. Irtautumisen tarinatyypissä keskeisenä elementtinä on luopuminen kolmannen iän tavoitteista ja suunnitelmista. (Vrt. Karisto 2004; Gilleard \& Higgs 2010.) Tarinassa aktiivinen eläkkeellä olon elämänvaihe kuihtuu pois, ja toiminta suuntautuu niihin asioihin, joita muistisairaus ei rajaa elämästä pois. Muistisairaus on arjessa läsnä, sen väistämätön eteneminen tiedostetaan, ja neljäs ikä pysyy etäällä keskittymällä tämän hetken elämään ja sairauden ulkopuolisiin asioihin. Aktiivisuuden tarinatyyppi sisältää monia yhtäläisyyksiä kolmanteen ikään sekä siihen kulttuurisesti liitettyihin tavoitteisiin, toimintaan ja arvostuksiin. Sairastumisen jälkeen, uudessa elämänvaiheessa, halutaan panostaa itselle tärkeisiin asioihin ja hyvinvointiin. Oman näköistä elämää suunnitellaan ja toteutetaan niin, että aktiivisuus ja toiminta voivat olla jopa monipuolisempaa kuin aikaisemmin. Sairauden etenemistä ja sen edustamaa neljättä ikää vastustetaan tietoisesti ja monin keinoin. Birtin ja kumppaneiden (2017) mukaan voidaan tunnistaa erilaisia liminaalisia tiloja, joissa muistisairauksiin sairastuneiden sosiaalinen osallisuus ja sairauteen suhtautuminen vaihtelevat. He tunnistivat kolme post-liminaalista tilaa: neljännen iän varjossa eläminen, aktiivinen kansalaisuus ja laajennettu liminaalisuus. Nämä tulokset tulevat lähelle tässä tutkimuksessa havaittuja tarinatyyppejä.

Sairauden alkuvaiheeseen liittyvissä kertomuksissa ensioireet ja sairauden toteaminen olivat merkityksellinen osa tarinaa. Ensioireet kuvattiin kaikilla tutkimukseen osallistuvilla epäselviksi, ja usean osallistujan kohdalla epäiltiin aluksi työuupumusta tai masennusta, mistä seurasi sairauslomia, jotka eivät kuitenkaan ratkaisseet tilannetta. Samoja huomioita on tehty aikaisemminkin (Johannessen \& Möller 2013; Hayo 2015; Rabanal ym. 2018). Muistisairauden toteaminen saattoi kestää pitkään, ja siihen sisältyi monia vaiheita sekä paljon tutkimuksia, ja sairauden diagnoosi oli yllätys ja aiheutti alkujärkytyksen. Työikäisillä muistisairauden diagnosointi tapahtuu hitaammin kuin iäkkäämpänä sairastuneilla (Draper ym. 2016), ja se voi tulla shokkina (Greenwood \& Smith 2016; Johannessen ym. 2019). Tässä tutkimuksessa kävi kuitenkin ilmi, että sairauden toteamiseen saattoi liittyä myös helpotuksen tunteita, koska pitkään jatkuneille oireille tuli näin selitys, ja osa-aikatyöhän siirtyminen vähensi työelämän kuormittavuutta, tai se jäi kokonaan pois eläkkeelle jäännin myötä.

Sairastuneiden ja läheisten kertomusten yhteneväisyydessä, resonoinnissa, oli eroa eri tarinatyyppien välillä. Sairastuneen ja läheisen jaettu tarina eli jaettu kokemus merkityksistä, pystyvyydestä ja yhteistoiminnasta voi olla selviytymistä tukeva voimavara. Tätä kutsutaan narratiiviseksi koherenssiksi. (Heimonen 2005.) Aikaisemmista tutkimuksista löytyy havaintoja, jotka ovat yhteneväisiä eri tarinatyypeistä esille nousseiden huomioiden kanssa. Clemmensen ja kumppanit (2019) havaitsivat kaksi erilaista läheisen roolia: sairastunutta suojeleva rooli ja päättäväisen toimijan rooli. Irtautumisen tarinatyypissä on yhteneväisyyttä läheisen päättäväisen toimijan roolin kanssa: sairastunut itse ei huomaa omia vaikuttamisen mahdollisuuksiaan, mutta läheinen koettaa päättäväisesti vaikuttaa asiaan. Tulevaisuuden suunnittelu nousi merkitykselliseksi läheisten näkemyksissä kaaoksen ja irtautumisen tarinatyypeissä. Läheisten tarve suunnitella tulevaisuutta on havaittu tyypilliseksi selviytymisstrategiaksi nimenomaan työikäisenä sairastuneiden läheisillä (Heimonen 2005; Wawrziczny ym. 2017). Aktiivisuuden tarinatyypissä sairastuneen ja läheisen kertomukset olivat yhteneviä siinä, että 
sairaus asetettiin pieneen roolin ja sairauden merkitystä pyrittiin tietoisesti minimoimaan elämäntilanteen kokonaisuudessa. Tällaista sairauden stigman heikentämistä sekä monipuolisia tunne- ja ratkaisukeskeisiä selviytymiskeinoja on havaittu aikaisemminkin työikäisenä sairastuneiden puolisohoitajilla (Lockeridge \& Simpson 2013).

Muistisairauden aiheuttamat muutokset ovat moninaisia, samoin sairastuneiden elämäntilanteet sekä käsitykset, joita sairastuneella ja hänen lähipiirillään on muistisairauksien vaikutuksista. Sairastuneen hyvinvointia tulee tukea hänen lähtökohdistaan käsin, ja tukemisen tavassa olisi syytä huomioida se, miten sairastunut suhtautuu muistisairauteen. Periksiantamattomuus, sairauden vastustaminen sekä korostetun optimistinen asennoituminen ovat joidenkin työikäisenä sairastuneiden selviytymisstrategioita uudessa elämäntilanteessa (Clemerson ym. 2014; Johannessen ym. 2018; Rabanal ym. 2018). Näitä, erityisesti aktiivisuuden tarinatyyppiin sisältyviä strategioita, on mahdollista tukea kannustamalla sairastuneita jatkamaan aktiivista elämäntapaa huomioiden samalla tiedolliset tuen tarpeet ja kokonaiskuormitus. Toiset muistisairauteen sairastuneet puolestaan katsovat parhaaksi vetäytyä monista aiemmista rooleistaan ja keskittyä vain olennaisiksi kokemiinsa asioihin ja tähän hetkeen. Tällöin tukemisessa on syytä kiinnittää huomiota sairastuneen aiempaan elämään sekä häntä kiinnostaviin asioihin ja rutiineihin. Aiemman elämäntyylin säilyttäminen, elämän jatkuvuus ja nykyhetkessä elämiseen keskittyminen parantavat useiden sairastuneiden elämänlaatua (Johannessen ym. 2018; Jaakkonen \& Vendell 2019), ja merkitykselliset toiminnot ylläpitävät tarpeellisuuden tunnetta (Greenwood \& Smith 2016; van Vilet ym. 2017; Rabanal ym.2018). Osallistumisen tukeminen sopivin keinoin on tärkeää, vaikka tavat toimia ja osallistua muuttuisivatkin sairauden myötä (van Vilet ym. 2017). Tuen tulee kohdistua myös läheiseen, jotta uuteen tilanteeseen sopeutuminen helpottuisi. Niillä sairastuneilla, joiden elämää muistisairauden kanssa hallitsee tunne kaaoksesta, on tärkeää keskittyä kokonaistilanteen hahmottamiseen, kuormittavien tekijöiden vähentämiseen ja hallinnantunteen lisäämiseen.

Tämän tutkimuksen tarjoama sairastuneiden kertoma kokemustieto lisää muiden ihmisten mahdollisuutta ymmärtää muistisairauden vaikutuksia ja omakohtaisia kokemuksia. Tutkimus tuo esille sairastuneiden omaa ääntä. Tulokset voivat auttaa työikäisenä muistisairauteen sairastunutta ja hänen läheistään tunnistamaan sairauden aiheuttamia elämänmuutoksia sekä jäsentämään omia kokemuksia, toimien näin tietoperäisenä vertaistukena. Muistisairautta sairastavien kanssa toimivat ammattilaiset ja vapaaehtoiset voivat hyödyntää tietoa erilaisista tarinatyypeistä omassa työskentelyssään yksilöllisen vaihtelun tunnistamisessa ja erilaisia tukemisen keinoja suunnitellessaan ja kokeillessaan. Erityisesti sairauden toteamisen jälkeiseen tukeen ja ohjaamiseen olisi tärkeä kiinnittää huomiota (Lockeridge \& Simpson 2013; Spreadbury \& Kipps 2019), ja tämän tutkimuksen tuottamaan tietoa voidaan hyödyntää siinä kehitystyössä. Jatkotutkimuksessa olisi kiinnostavaa tarkastella, miten nyt esille nousseet tarinatyypit hahmottuisivat toisenlaisesta, esimerkiksi yli 65-vuotiaana muistisairauteen sairastuneiden, aineistosta. Työikäisten muistisairauksien sairastamisen prosessia toisi laajemmin esille seurantatutkimus, jossa tarkasteltaisiin sekä tarinatyyppien olemassaoloa että niiden muuntumista. Ymmärrystä muistisairauden vaikutuksista lisäisi myös läheisten rooliin liittyvä tutkimus ja huomion kiinnittäminen siihen, miten sairastumisen jälkeinen elämäntarinan uudelleen rakentaminen tapahtuu sairastuneen ja läheisen yhteisenä prosessina.

\section{Yhteydenotto:}

Katja Hautsalo, TtM, sh, th, lh tohtoriopiskelija (sosiaalitieteet) lehtori, terveysyksikkö, Tampereen ammattikorkeakoulu katja.hautsalo@helsinki.fi 


\section{Kirjallisuus}

Baptista MA, Santos RL, Kimura N, Lacerda IB, Johannenssen A, Barca ML ym. Quality of life in young onset dementia: an updated systematic review. Trends Psychiatry Psychother 2016; 38(1):6-13. https://doi.org/10.1590/2237-6089-2015-0049

Birt L, Poland F, Csipke E, Charlesworth G. Shifting dementia discourses from deficit to active citizenship. Sociol Health Illn 2017;39(2):199-211. https://doi.org/10.1111/1467-9566.12530

Bury M. Chronic illness as biographical distruption. Sociol Health Illn 1982;4(2):167-82. https://doi.org/10.1111/1467-9566.ep11339939

Clemerson G, Walsh S, Isaac C. Towards living well with young onset dementia: an exploration of coping from the perspective of those diagnosed. Dementia 2014;13(4):451-66. https://doi.org/10.1177\%2F1471301212474149

Clemmensen TH, Busted LM, Søborg J, Bruun P. The family's experience and perception of phases and roles in the progression of dementia: an explorative, interview-based study. Dementia 2019;18(2):490-513. https://doi.org/10.1177/1471301216682602

Coll-Planas G, Visa M. The wounded blogger: analysis of narratives by women with breast cancer. Sociol Health Illn 2016;38(6):884-98. https://doi.org/10.1111/1467-9566.12405

Draper B, Cations M, White F, Trollor J, Loy C, Brodaty $\mathrm{H}$ ym. Time to diagnosis in young-onset dementia and its determinants: the INSPIRED study. Int J Geriatr Psychiatry 2016;31(11):121724. https://doi.org/10.1002/gps.4430

Frank AW. The wounded storyteller: body, illness, and ethics. 2nd ed. Chicago: University of Chicago Press, 2013.

Gilleard C, Higgs P. Aging without agency: theorizing the fourth age. Aging Ment Health 2010;14(2):121-8. https://doi.org/10.1080/13607860903228762

Greenwood N, Smith R. The experiences of people with young-onset dementia: a meta-ethnographic review of the qualitative literature. Maturitas 2016;92:102-9. https://doi.org/10.1016/j.maturitas.2016.07.019

Gullette MM.Against'aging'- how to talk about growing older. Theory Cult Soc 2018;35(7-8):251-70. https://doi.org/10.1177/0263276418811034
Hayo H. Diagnosis and support for younger people with dementia. Nurs Stand 2015;29(47):36-40. https://doi.org/10.7748/ns.29.47.36.e9197

Heimonen S. Työikäisenä Alzheimerin tautiin sairastuneiden ja heidän puolisoidensa kokemukset sairauden alkuvaiheessa. Jyväskylä: Jyväskylän yliopisto, 2005.

Higgs P, Gilleard C. Ageing, dementia and the social mind: past, present and future perspectives. Sociol Health Illn 2017; 39(2):175-81. https://doi.org/10.1111/1467-9566.12536

Hydén LC. Illness and narrative. Sociol Health Illn 1997;19(1):48-69.

Hyvärinen M. Haastattelukertomuksen analyysi. Teoksessa: Ruusuvuori J, Nikander P, Hyvärinen M. Haastattelun analyysi. Tampere: Vastapaino, 2010:90-118.

Hänninen V. Coping with unemployment as narrative reorientation. Nordiske Udkast 1996;24(2):1932.

Hänninen V. Sisäinen tarina, elämä ja muutos. Tampere: Tampereen yliopisto, 1999.

Jaakkonen NM, Vendell EI. Täsä vielä pörrätään täällä pitkään - työikäisenä muistisairauteen sairastuneiden ihmisten kokemuksia sairaudestaan. Gerontologia 2019;33(4):190-203.

Johannessen A, Engedal K, Haugen PK, Dourado $\mathrm{MC}$, Thorsen K. Coping with transitions in life: a four-year longitudinal narrative study of single younger people with dementia. J Multidiscip Healthc 2019;12:479-92. https://doi.org/10.2147/JMDH.S208424

Johannessen A, Engedal K, Haugen PK, Dourado $\mathrm{M}$, Thorsen K. "To be, or not to be": experiencing deterioration among people with young-onset dementia living alone. Int J Qual Stud Health Well-being 2018;13(1):1-13. https://doi.org/10.1080/17482631.2018.1490620

Johannessen A, Möller A. Experiences of persons with early-onset dementia in everyday life: a qualitative study. Dementia 2013;12(4):410-24. https://doi.org/10.1177/1471301211430647

Karisto A. Kolmas ikä - uusi näkökulma väestön vanhenemiseen. Teoksessa: Kautto M. Ikääntyminen voimavarana: tulevaisuusselonteon liiteraportti 5 . Valtioneuvoston kanslia, 2004:91-103.

Kuula A. Tutkimusetiikka: aineistojen hankinta, käyttö ja säilytys. Tampere: Vastapaino, 2011. 
Lockeridge S, Simpson J. The experience of caring for a partner with young onset dementia: how younger carers cope. Dementia 2013;12(5):63551. https://doi.org/10.1177/1471301212440873

McParland P, Kelly F, Innes A. Dichotomising dementia: is there another way? Sociol Health Illn 2017;39(2):258-69.

https://doi.org/10.1111/1467-9566.12438

Millenaar J, Bakker C, Koopmans R, Raymond T, Verhey F, Kurz A ym. The care needs and experiences with the use of services of people with young-onset dementia and their caregivers: a systematic review. Int J Geriatr Psychiatry 2016;31(12):1261-76.

https://doi.org/10.1002/gps.4502

Muistisairaudet. Käypä hoito -suositus. Suomalaisen Lääkäriseuran Duodecimin, Societas Gerontologica Fennican, Suomen Geriatrit -yhdistyksen, Suomen Neurologisen Yhdistyksen, Suomen Psykogeriatrisen Yhdistyksen ja Suomen Yleislääketieteen yhdistyksen asettama työryhmä. Helsinki: Suomalainen Läkäriseura Duodecim, 2017.

O'Bryant SE, Waring SC, Cullum CM, Hall J, Lacritz L, Massman PJ ym. Staging dementia using Clinical Dementia Rating Scale Sum of Boxes scores: a Texas Alzheimer's research consortium study. Arch Neurol 2008;65(8):1091-5.

https://doi.org/10.1001/archneur.65.8.1091

Pietilä I, Jurva R, Ojala H, Tammela T. Seeking certainty through narrative closure: men's stories of prostate cancer treatments in a state of liminality. Sociol Health Illn 2018;40(4):639-53. https://doi.org/10.1111/1467-9566.12671

Pinnock H, Kendall M, Murray SA, Worth A, Levack $P$, Porter $M y m$. Living and dying with severe chronic obstructive pulmonary disease: multi-perspective longitudinal qualitative study. BMJ (Clinical research ed.) 2011;342:d142. https://doi.org/10.1136/bmj.d142

Pirhonen J, Ojala H,Lumme-Sandt K, Pietilä I. 'Old but not that old': Finnish community-dwell- ing people aged 90 negotiating their autonomy. Ageing Soc 2015;36(8):1625-44.

https://doi.org/10.1017/S0144686X15000525

Rabanal L, Chatwin J, Walker A, O'sullivan M, Williamson $\mathrm{T}$. Understanding the needs and experiences of people with young onset dementia: a qualitative study. BMJ Open 2018;8:e21166. 10.1136/bmjopen-2017-021166

Rosenvall A. Ohjeita CDR-luokitukseen, 2016. Internet: https://www.kaypahoito.fi/nix00512 (viitattu 1.10.2020).

Saarenheimo M.Jos etsit kadonnutta aikaa. Tampere: Vastapaino, 1997.

Spreadbury JH, Kipps C. Measuring younger onset dementia: what the qualitative literature reveals about the 'lived experience' for patients and caregivers. Dementia 2019;18(2):579-98.

https://doi.org/10.1177/1471301216684401

Van Vliet D, Persoon A, Bakker C, Koopmans R, De Vugt M, Bielderman A, Gerritsen D. Feeling useful and engaged in daily life: exploring the experiences of people with young-onset dementia. Int Psychogeriatr 2017;29(11):1889-98.

https://doi.org/10.1017/S1041610217001314

Wawrziczny E, Pasquier F, Ducharme F, Kergoat MJ, Antoine P. Do spouse caregivers of persons with early- and late-onset dementia cope differently? A comparative study. Arch Gerontol Geriatr. 2017;69:162-168.

doi: 10.1016/j.archger.2016.12.002. Epub 2016

Williams G. The genesis of chronic illness: narrative re-construction. Sociol Health Illn 1984;6(2):175-200.

https://doi.org/10.1111/1467-9566.ep10778250

Williams SJ, Higgs P, Katz S. Neuroculture, active ageing and the 'older brain': problems, promises and prospects. Sociol Health Illn 2012;34(1): 64-78.

https://doi.org/10.1111/j.1467-

9566.2011.01364.x 